原著

胃良性疾患に対する胃部分切除後長期経過例に扣ける残胃粘膜の变化 一残胃癌発生の risk に関する検討一

\begin{tabular}{lllll} 
& \multicolumn{3}{c}{ 弘前大学第 2 外科 } \\
小澤 & 正則 & 三上 & 泰徳 \\
羽田 & 隆吉 & 小野 & 慶一
\end{tabular}

\title{
LONG TERM OBSERVATION OF GASTRIC MUCOSA FOLLOWING \\ PARTIAL GASTRECTOMY FOR BENIGN CONDITIONS : CHRONIC GASTRITIS OF REMNANT STOMACH IN PATHOGENESIS OF CARCINOMA
}

\author{
Masanori OZAWA, Yasunori MIKAMI, Yuzuru SUGIYAMA, \\ Ryukichi HADA and Keiichi ONO
}

2nd Department of Surgery, Hirosaki University School of Medicine

\begin{abstract}
胃良性疾患のため胃部分切除を施行し Billroth II 法で再建した43例について術後 $7 〜 21$ 年 6 力月 経過後の胃粘膜を検討対象とした. 内視鏡所見では吻合部の発赤・びらんは $30.3 \%$ ，ポリープ病変は 11.6\%にみられたが，これと胆汁逆流との因果関係は明らかでなかった. 残胃生検標本に扎いて固有 胃腺萎縮の程度は吻合部に最も高度で, その改筑像としての偽幽門腺化, 腺管莀胞状拡張および腺管 異型の所見る同部に高頻度で出現した. しかし術後15年を境に症例を 2 群に区分して各組織所見の出 現頻度を比較すると後半の症例で増加する傾向は認められなかった。 また腸上皮化生が残胃に新生し たものは $4.7 \%$ と著しく低率であることを指摘した。
\end{abstract}

索引用語：慢性萎縮性胃炎，残胃癌，幽門側胃部分切除術，Billroth II 法，呺上皮化生

\section{I.はじめに}

胃部分切除後の残胃に癌の発生を最初に報告したの は1930年 Eichelter 1)とされている. その後, ことに 1950年代以降, 欧米では胃部分切除後に Billroth II 法 で再建されて長期に経過した症例の残胃には general populationに比較して発癌の risk が高いとの報告を

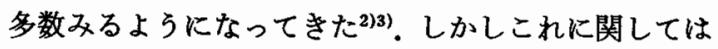
かならずしも意見の一致をみているとはいえないのが 現状である(4) 6).

そこで著者らは教室に招いて胃良性疾患のため幽門 側胃切除が施行され Billroth II 法で再建された症例 の5ち長期経過例について胃粘膜を内視鏡ならびに生 検により観察したところ, 発癌の risk につき若干の知

$<1985$ 年11月 12 日受理 $>$ 別刷請求先：小澤 正則 T036 弘前市在府町 5 弘前大学医学部第 2 外科
見を得たので報告する.

$$
\text { II. 対象および方法 }
$$

弘前大学第 2 外科において昭和 36 年 8 月より 51 年 5 月までの 14 年 9 カ月間に胃良性疾患のため幽門側胃切 除を施行し, 再建術式として Billroth II 法を採用され たものは242例あった。このうち昭和 58 年 2 月現在生存 し検査の呼び出しに応じたもの43例 (17.8\%) を対象 とした。これら43例の原疾患は消化性潰瘍39例, 慢性 胃炎 1 例, 胃ポリープ 3 例で, 検査時に括ける術後経 過期間は 7 年より 21 年 6 カ月に及んでいた。性別は男 39 例, 女 4 例で検查時年齢は $35 \sim 83$ 歳 (平均 60.4 歳) であった。検査は身体状況に関する問診, 理学的検査, 末梢血, 血液生化学検查ならびに内視鏡と直視下生検 とともに胃内の胆汁酸と細菌叢検査をおこなった。本 稿はこのうち内視鏡所見拉よび生検標本の組織学的検 査の結果を報告する。 
図 1 生検部位

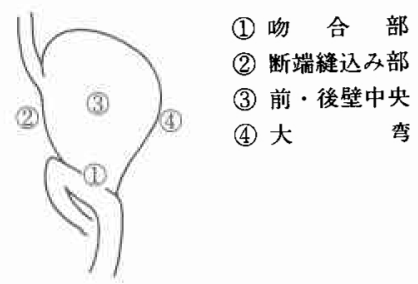

生検部位は図 1 に示すように, (1)胃空腸吻合部, (2) 胃断端縫込み部，(3)前壁または後壁中央，(4)大弯の 4 点と定めた. 得られた生検数は184個で,この標本を粘 膜筋板側に目印のため点墨の上, 垂直に薄切しへマト キシリン・エオシン重染色を施し鏡検した。組織診断 可能な標本数は159個であった. また腸上皮化生の検討 のために初回切除標本を対照として検索した。

組織所見の記載にあたっては，固有胃腺の萎縮程度 の表現に大井ら ${ }^{7)}$ の判定基準を用い，また腺管異型に 関してはMorson ${ }^{8}$ の区分に準拠した。

また結果の信頼性については $\chi^{2}$ 検定法にイェーッ の補整を施して統計処理した。

\section{III. 結 果}

\section{A. 内視鏡所見}

内視鏡検查時，胃内に胆汁貯留を認めたものは43例 中16例 $(37.2 \%)$ で，残る27例 $(62.8 \%)$ に扎いては 胆汁を認めなかった。 そこで胆汁の胃内貯留と内視鏡 所見，とくに吻合部における発赤・びらんとポりープ 病変との関係について検討を抗こなった. 吻合部発 赤・びらんは43例中13例 $(30.3 \%)$ にあり，このらち 胃内胆汁貯留をともなったものは 7 例(16.3\%)であっ た.一方胆汁の逆流なく発赤・びらんを認めたすのは 6 例 $(14.0 \%)$ であり, 逆に胆汁の逆流はあっても発 赤•びらんの出現していないものも 9 例 (20.9\%) あっ た.これを統計的に処理すると胆壮逆流と吻合部発 赤・びらんには有意の関係はみられなかった（p> 0.10)（表 1).

一方，吻合部におけるポリープ病変については，43 例中 5 例 $(11.6 \%)$ に観察された。これを胃内胆汁逆 流との関係からみると，胆汁とポリープ病変とを同時 に認めたものは 1 例 $(2.3 \%)$ ので, ほかの 4 例 (9.3\%) には胆汁との関係は明らかでなかった。これ を統計的にみると，ポリープ病変の出現と残胃内胆汁 貯留との間には有意の関係はみとめることができな かった（p>0.10）（表 2 ）.

B. 生検組織所見
表 1 吻合部発赤・びらん

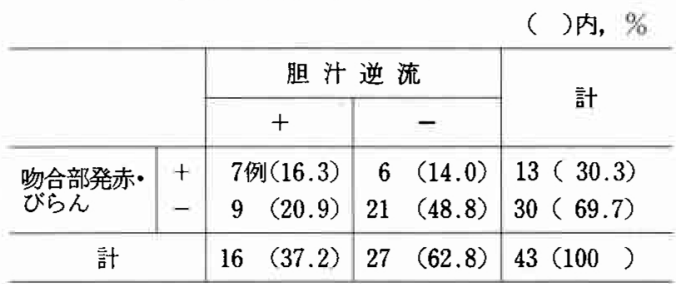

表 2 吻合部ポリープ )内, $\%$

\begin{tabular}{|c|c|c|c|c|}
\hline & & \multicolumn{2}{|c|}{ 胆 汁逆流 } & \multirow{2}{*}{ 計 } \\
\hline & & + & - & \\
\hline \multirow{2}{*}{$\begin{array}{l}\text { ポリープ } \\
\text { 病変 }\end{array}$} & + & 1例 ( 2.3) & $4(9.3)$ & $5(11.6)$ \\
\hline & - & $15 \quad(34.9)$ & $23(53.5)$ & $38(88.4)$ \\
\hline \multicolumn{2}{|l|}{ 計 } & $16 \quad(37.2)$ & $27 \cdot(62.8)$ & $43(100)$ \\
\hline
\end{tabular}

1. 固有胃腺の萎縮程度と部位別頻度

残胃43例の生検組織標本に打ける慢性胃炎を Schindler ${ }^{\text {9) }}$ 分類に準拠して診断した。この結果, 表層性 胃资，肥厚性胃炎の所見は認められず，程度は種々で あってる全例が萎縮性胃炎の所見を旺した。そこで固 有胃腺の萎縮程度を大井らの判定基準》に則して 3 段 階に分けると，萎縮が軽度にとどまるすのは 4 例 (9.3\%)，中等度21例 (48.8\%), 高度にみられるむの 18例（41.9\%）であった。

そこで固有胃腺の萎縮程度と部位別に比較してみ た。 その結果は表 3 に示す通り吻合部に拈いては全例 萎縮を呈したが，他部位では病的所見のない症例が 9.5〜 12.8\%にみられた.萎縮を認めた症例のうち軽度 萎樎を示したものは吻合部において43例中 4 例 (9.3\%) と低く，断端縫込み部では42例中11例 $(26.2 \%)$ ，前・後壁中央は 43 例中15例 $(34.9 \%)$ ，大弯 39例中22例（56.4\%）の順に上昇をみた。吻合部の軽 度萎縮を呈する頻度は最す低率で断端縫込み部との間 には $\mathrm{p}<0.05$ で有意差があり，また前・後壁および大弯 との間にもそれぞれ $\mathrm{p}<0.01$ で有意差が検定された。 一方, 高度萎縮の出現頻度についてみると, 吻合部に おいては43例中18例（41.9\%）と他部位に比較して著 明に高く，断端縫込み部ならび前・後壁における頻度 との間にはいずれす $\mathrm{p}<0.01$ で有意差を認めた。

2. 組織所見と部位別出現頻度

固有胃腺の萎縮とともに出現した組織所見はお括む ね腺管異型, 腺管囊胞状拡張, 偽幽門腺化, 細胞渗潤, 腸上皮化生，浮腫などであった．各組織所見の出現頻 
表 3 部位別にみた固有胃腺萎縮の程度

\begin{tabular}{|c|c|c|c|c|c|}
\hline & & 吻 合 部 & 断端敕込み部 & 前・後壁 & 大弯 \\
\hline $\begin{array}{l}\text { 固樎 } \\
\text { 㤫の } \\
\text { 胃程 } \\
\text { 葲度 }\end{array}$ & $\begin{array}{c}\text { なし } \\
\text { 軽度 } \\
\text { 中等度 } \\
\text { 高度 } \\
\end{array}$ & 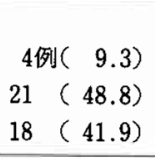 & $\begin{array}{c}4 \quad(9.5) \\
11^{* *}(26.2) \\
25(59.5) \\
2^{*}(4.8)\end{array}$ & 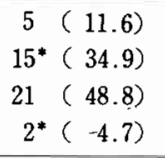 & $\begin{array}{cc}5 & (12.8) \\
22^{*} & (56.4) \\
12 & (30.8)\end{array}$ \\
\hline \multicolumn{2}{|c|}{ 計 } & $43(100)$ & $42(100)$ & $43(100)$ & $39(100)$ \\
\hline
\end{tabular}

表 4 部位別組織所見

\begin{tabular}{|c|c|c|c|c|c|}
\hline & 吻 合 部 & 断端縫込み部 & 前 - 後壁 & 大 & 弯 \\
\hline 腺管異型 & 26 例 $(60.5)$ & $7^{*}(16.7)$ & $6^{*}(14.0)$ & & \\
\hline の5胞状扩張 & $21 \quad(48.8)$ & $7^{*}(16.7)$ & $2^{*}(4.6)$ & $1^{*}$ & ( 2.6) \\
\hline 偽幽門腺化 & 17 (39.5) & $9(21.4)$ & $7 \quad(16.3)$ & 6 & (15.4) \\
\hline 細胞渗潤 & 18 (41.9) & $28 \quad(66.7)$ & $25 \quad(58.1)$ & 23 & $(59.0)$ \\
\hline 腸上皮化生 & $5 \quad(11.6)$ & $4(9.5)$ & $3(7.0)$ & 4 & $(10.3)$ \\
\hline 浮嗹 & & $1(2.4)$ & $2(4.6)$ & 1 & $(2.6)$ \\
\hline その他 & $1(2.3)$ & $1(2.4)$ & $1(2.3)$ & 2 & ( 5.2$)$ \\
\hline 病的所見なし & & $4(9.5)$ & $5 \quad(11.6)$ & 5 & (12.8) \\
\hline 検索標本数 & 43 & 42 & 43 & 39 & \\
\hline
\end{tabular}

度を部位別にみると表 4 に示すような結果となった。 すなわち腺管異型についてみると，吻合部では $60.5 \%$ にみられたが断端縫込み部では $16.7 \%$, 前・後壁は $14.0 \%$ と著明に低下し，大弯には認められなかった。 吻合部に拈ける頻度は他部位より高く，その間にはい ずれも $\mathrm{p}<0.01 て ゙$ 有意差をみとめた.

腺管变胞状拡張および偽幽門腺化の所見において も，その出現頻度は腺管異型より低值ではあるが，部 位別出現頻度の傾向は同様に吻合部で高く断端縫込み 部, さらに前・後壁, 最後に大弯の順に低下し, これ らの変化は固有胃腺の萎縮程度に相応した。これらの 所見のらち襄胞状払張には吻合部々他部位との間に $\mathrm{p}<0.01$ で有意差を認めたが，偽幽門腺化については 統計的に差がなかった $(\mathrm{p}<0.05)$.

3. 腺管異型の程度と部位別頻度

慢性胃炎に打湶管異型の程度をMorsonの分 類泉に準拠して 3 段階に区分し，その出現頻度を部位 別に検討した。吻合部の観察では腺管異型のないるの は43例中18例（41.9\%）を占め，他部位に比べ有意に 低い頻度を示した（p<0.01）。一方異型を認めた25例 (58.1\%)について，その程度をみると異型軽度のるの
表 5 部位別にみた腺管異型の程度

\begin{tabular}{|c|c|c|c|c|c|}
\hline & & 吻 合 部 & 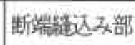 & 前 - 後壁 & 大 弯 \\
\hline $\begin{array}{l}\text { 腺程 } \\
\text { 管度 } \\
\text { 型 } \\
\text { 等 }\end{array}$ & $\begin{array}{c}\text { なし } \\
\text { 軽度 } \\
\text { 中等度 } \\
\text { 高度 }\end{array}$ & $\begin{array}{rr}18 \text { 例 } & (41.9) \\
7 & (16.3) \\
10 & (23.3) \\
8 & (18.6)\end{array}$ & $\begin{array}{rr}35^{*} & (83.3) \\
3 & (7.1) \\
3 & (7.1) \\
1^{* *} & (2.5)\end{array}$ & $\mid \begin{array}{rr}37^{*} & (86.0) \\
4 & (9.3) \\
2 * * & (4.7)\end{array}$ & $39^{*}(100)$ \\
\hline \multicolumn{2}{|c|}{ 検索標本数 } & 43 & 42 & 43 & 39 \\
\hline
\end{tabular}

7 例 $(16.3 \%)$, 中等度10例 $(23.3 \%)$, 高度 8 例 (18.6\%) であった．高度の異型を呈する頻度を部位別に比較す ると, 吻合部における18.6\%は断端䋖込み部の $2.6 \%$ よび前・後壁4.7\%より高く，この間に有意差をみとめ た $(\mathrm{p}<0.05)$.

なお大弯より採取された 39 例の生検切片には，いず れる腺管異型を認めなかった（表 5 ）.

4. 残胃之腸上皮化生

残胃に抎いて腸上皮化生を認めたものは 7 例あり， 43例中の $16.3 \%$ に相当した。 この腸上皮化生の由来を 
表 6 腸上皮化生

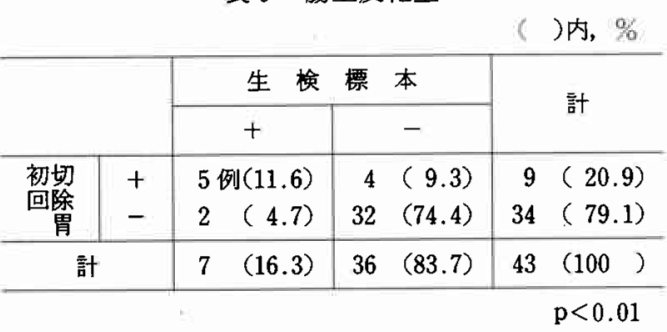

表 7 吻合部組織所見と術後期間

\begin{tabular}{|c|c|c|c|}
\hline & $\begin{array}{r}15 \text { 年末满 } \\
22 \text { 例 }\end{array}$ & $\begin{array}{l}15 \text { 年以上 } \\
21 \text { 例 }\end{array}$ & 計 ${ }_{43 \text { 例 }}$ \\
\hline 腺管異 型 & 12例(54.5) & 14 例 $(66.7)$ & 26例 (60.5) \\
\hline のう胞状拡張 & $13 \quad(59.1)$ & $8 \quad(38.0)$ & $21 \quad(48.8)$ \\
\hline 偽幽門腺化 & $9 \quad(40.9)$ & $8 \quad(38.0)$ & $17 \quad(39.5)$ \\
\hline 細胞 渗 潤 & $11 \quad(52.4)$ & 7 (33.3) & 18 (41.9) \\
\hline 腸上皮化生 & $3 \quad(13.6)$ & $2(9.5)$ & $5 \quad(11.6)$ \\
\hline $\begin{array}{c}\text { その他 } \\
\text { 病的所見なし }\end{array}$ & & $1(4.8)$ & $1(2.3)$ \\
\hline
\end{tabular}

知るため初回切除標本に抢ける腸上皮化生の分布範囲 を比較検討した。切除標本に括いて腸上皮化生が広範 型を呈したものは 9 例 (20.9\%) あり，このらち残胃 生検でも腸上皮化生を認めたものは 5 例あった。これ らの症例では術前より存在した腸上皮化生の口側部分 が残胃に遺残したものと判断された。したがって残胃 に腸上皮化生が新たに出現した可能性を有するすのは 2 例にすぎず, この頻度は 43 例中の $4.7 \%$ に相当し, 統 計的には $\mathrm{p}<0.01 て ゙$ 有意差を認めた（表 6 ）.

5. 街後経過期間と組織所見の変化

組織学的変化の最も著しい吻合部に拈いて術後経過 期間が組織所見に及ぼす影響を検討した，各組織所見 の出現頻度を比較するため便宜的に術後15年を境界に 症例を 2 群に区分すると，15年末満群は22例，15年以 上群が21例となった。そこでまず腺管異型についてみ ると15年未満群では 22 例中 12 例 $(54.5 \%)$ であり， 15 年以上群21例に打いては14例 $(66.7 \%)$ と幾分増加傾 向がうかがわれたが有意差はなかった（ $\mathrm{p}>0.10 ）$ 。 た襄胞状腺管拡張，偽幽門腺化をはじめほかの所見に おいても増加は認められなかった $(\mathrm{p}>0.10)$ (表 7 ).

この結果, 固有胃腺の萎縮性变化とその改築像とし ての種々の所見は, 今回検討対象として扱った術後 7 年以降の症例では，その頻度を上昇させることなく継 続することが示された。
IV. 考 案

一般に胃部分切除後の残胃に慢性胃炎の発生する原 因としては，1）十二指腸内容の逆流，2）幽門前庭部 切除による gastrin 分泌の低下と壁細胞，主細胞の被 刺激性の減退, 3) 手術操作に基づく血行の变化などが 挙げられている。ささらに胃粘膜損傷の程度は再建術式 によっても大きな差があり，したがって残胃癌発生の riskるこれによって左右されるとの報告がある。すな わち実験的ならびに臨床的な比較の結果, Billroth II 法は Billroth I 法より発癌率は高いと述べられてお $\eta^{10) \sim 14)}$, この原因の 1 つとして十二指腸液の胃内逆流 が重視されている。指腸液中には 2 次胆汁酸を含 みその化学的刺激が胃粘膜を障害するだけでなく，逆 流のため起こる $\mathrm{pH}$ の上昇が胃内細菌叢の増殖をるた らし,とくに fecal flora の出現は bile acidなど enterogenous steroid から carcinogen を産生すると報告2) されている。また細菌の中でもClostridium 属は食物 中の硝酸塩を分解して N-nitroso 化合物を含む亜硝酸 塩を産生するとの発表 ${ }^{15}$ るられる。

さて残胃癌の初期肉眼型に関しては高橋ら ${ }^{16)}$ の報告 がある.すなわち残胃早期癌 12 例の肉眼型は I 型 5 例, IIa 1例, IIb 1例, IIc 5例であり, 隆起型 6 例に対して 陥凹型は 5 例とほぼ同数であったが IIc+III, III 型の 潰瘍病変をともなら症例は認めなかったというもので ある。これは癌との鑑別や癌の発生母地となる危険性 からみて発赤・びらんとポリープ病変とはとくに注意 深く観察すべき所見であることを示唆している。そこ で著者らはこれらの所見を癌の好発する吻合部に执い て検討してみた訳である。

Billroth II 法後の吻合部における発赤・びらんにつ いて中島 ${ }^{11}$ は119例の検討から発赤 $52.9 \%$ ，びらん $15.9 \%$ と述へ，著者らの 43 例中 13 例（30.3\%）上り高 い頻度を報告している．またポリープ病変の出現頻度

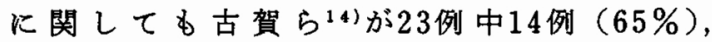
Kobayashi ${ }^{12)}$ らは25例中10例 (40\%) と述べているが, いずれる著者らの 43 例中 5 例 $(11.6 \%$ ）に比較すると かなり高い値を示している。

そこでこれらの所見に対する十二指腸液の影響をみ るため胃内の bile poolingについて検討した，中島 $ら^{11}$ は内視鏡検查時, 残胃内に胆汁を認めたものは $6.0 \%$ と報告しているが，著者らの43例中では 7 例 (16.3\%)とやや高い傾向を示した。しかし残胃におけ る発赤・びらんおよびポリープ病変との関係をみると， 胆汁とこれらの所見が共存している頻度は低く，両者 
間に因果関係を推定することはできなかった，

胃腸吻合部に生じるポリープ病変は Littler ら ${ }^{17) か ゙ ~}$ 1972年 gastritis cystica polyposa として報告して以

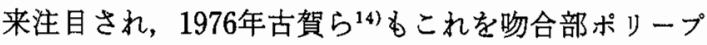
状肥厚性胃炎と名付けて発表した。彼らによるとその 組織像は胃小窩の延長, 偽幽門腺化掞よび腺管襄胞状 拡張を主体とし，胃底腺は激減するが腸上皮化生巣は みられないとされている，著者らはこうした一連の変 化は固有胃腺の萎縮過程を表現するすのであり，また Moszkowicz ${ }^{18}$ )の慢性胃炎の見解に基づくと，粘膜の 受けた損傷の程度とそれに対する固有の再生能力に応 じた改築像を示すむのと解釈し, 癌はここを出発点と して発生, 進展するものと推定している.

そこで大井らの判定基準》に基づいて固有胃腺の萎 縮程度をみると, 高度の萎縮性変化は吻合部で高頻度 に発生し他部位に比較すると有意の差を認めた。一方， 萎縮にともなら改築像としての組織所見には腺管異 型, 腺管囊胞状抎張および偽幽門腺化などがあったが, その程度と出現頻度とは吻合部に顕著であり, 固有胃 腺萎縮の傾向と相呼応する変化を示した。これらの結 果は Billroth II 法の吻合部には癌化の risk が高いこ とを示唆するものと判断された。

一方, 残胃癌発生には術後長い経過期間の必要なこ とを指摘する臨床報告があり，主に欧米に多くみられ $3^{233112219) 201}$. それらの報告からすると術後の組織所見 は時間の経過とともに漸次癌への道を進行するもので あり，したがって慢性萎縮性胃炎にはその性質が潜在

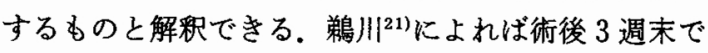
すでに 9 例中 4 例は明らかな萎縮を認めたが， 2 年末 満で $50 \% ， 2$ 年以上でも $70 \%$ にととまるとして，萎縮 は早期に発現してその後緩徐に進行する傾向にあると 報告されている，また，Gjeruldsen ら ${ }^{22)}$ は術後 3 力月

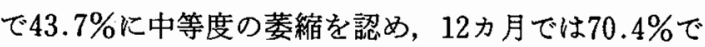
中等度または高度の萎縮があったと述べている。

しかしながら Kobayashi ら ${ }^{12)}$ は術後短期間で高度 萎縮の夕られた例や，10年後も萎縮は軽度だった例を 挙げて萎縮性胃炎が進行性であるとの実証はなかった と述べている。さらに, Palmer ${ }^{23}$ も術後胃炎は数週よ り数年にわたり同じ性質を示すとしてその進行性につ いては否定的である。著者らの 43 例は術後 7 年 21 年 6 力月と長期に経過して预り, 便宜的に 15 年で 2 群に 区切って比較した結果からみると, 両群の間には組織 学的所見とその頻度に差異を認めることができなかっ た. 少なくとも残胃粘膜の所見は今回検討の対象とし
て扱った術後 7 年以降の症例に括いては, ほとんど進 行せず経過するものと判断された。 したがって発癌に 占める時間的要因の重要性に関しては実証されなかっ た。

ここで一般に癌発生母地として注目されている腸上 皮化生について検討してみた。残胃の腸上皮化生は 7 例あり, このらち 5 例は初回切除胃に打いて広範型を 示して拉り，腸上皮化生は残胃断端に遺残したものと 考えられた。残胃で腸上皮化生が新生した可能性をる つものは 2 例 (4.7\%) と少数にすぎず, 萎縮性胃炎の 改筑像としては頻度も低く, 術後経過につれて増加傾 向もないことょり, 残胃癌の発生母地としての関連性 は強くないものと判断された。

\section{V.まとめ}

教室において胃良性疾患のため幽門側胃切除を施行 し, 再建術式として Billroth II 法を採用された症例の らち, 術後 7 年 21 年 6 力月経過した 43 例に対して内 視鏡㧍よび生検を施行し以下の結果をえた。

1）内視鏡検查で吻合部に発赤・びらんの所見を認め たものは43例中13例 $(30.3 \%)$ で，ポリープ病変は 5 例 (11.6\%) であった. しかしこれらの所見と十二指 腸液逆流との因果関係は明らかでなかった。

2) 残胃の 4 力所(1)吻合部, (2)断端縫込及部, (3)前・ 後壁中央, (4)大弯) から内視鏡下に生検を打こない, その組織所見から次の点を指摘した。

a）胃底腺萎縮の程度は吻合部に扣いて最子高度 で, その改築像として出現する為幽門腺化, 腺管囊胞 状拡張および腺管異型の所見も同部に高頻度でみられ た。これは Billroth II 法で発癌の risk が上昇すること を示唆するものと判断された。

b）一方, 術後 15 年を境に 2 群に区分し組織所見と その出現頻度を比較すると,両群の間に有意差はなく, 発癌で占める時間的要因の重要性に関しては実証され なかった。

c）残胃に腸上皮化生の新生されたものは43例中 2 例 $(4.7 \%)$ にすぎなかった。

\section{文献}

1) Eichelter G: Spontanperforation des paralytischerweiterten Duodenalschenkels wegen Ulcus. Dtsch Z Schr Chir 222 : 106-114, 1930

2) Domellöf L, Reddy BS, Weisburger JH : Microflora and Deconjugation of Bile Acid in Alkaline Reflux After Partial Gastrectomy. Am J Surg $140: 291-295,1980$

3) Stalsgerg H, Taksdal S: Stomach cancer fol- 
lowing gastric surgery for benign condition. Lancet $27: 1175-1177,1971$

4) Peters H, Schugert HJ: Das Carcinom im Restmagen nach Resektion wegen gutartiger Befunde. Langenbecks Arch Chir 336: 219-233, 1974

5) Nicholls JC: Stump cancer following gastric surgery. World J Surg 3 : 731-736, 1979

6）徳留信寛, 吉野純典, 池田正人民か：胃・十二指腸 の良性疾患に対する胃切除後の残胃初発癌. 胃之 腸 $17: 1295-1301,1982$

7）大井 実, 奥脇晴雄：胃炎の胃鏡所見と組䋺像と の関係について. 臨消病 6:335-352, 1958

8) Morson BC, Sobin LH, Grundmann $\mathrm{E}$ et al : Precancerous conditions and epithelial dysplasia in the stomach. J Clin Pathol 33 : 711-721, 1980

9) Schindler $\mathrm{R}$ : Chronische Gastritis. Klin Wockensch $44: 601-612,1966$

10) Langhans $P$, Heger RA, Hohenstein $J$ et al : Operation-sequel carcinoma of the stomach. World J Surg 5:595-605, 1981

11）中島敏夫：術後胃炎. 胃之腸 $2 ： 1399-1405$, 1967

12) Kobayashi S, Prolla JC, Kirsner JB: Late gastric carcinoma developing after surgery for benign conditions. Dig Dis Sci $15: 905-912$, 1970

13) Morgenstern L, Yamakawa T, Seltzer D: Carcinoma of the gastric stump. Am J Surg
$125: 29-38,1973$

14）古賀 淳, 渡辺英伸, 遠城寺宗知：胃腸吻合部に見 られるポリープ状病変。福岡医誌 $69: 285-296$, 1976

15) Muscroft TJ, Deane SA, Youngs D et al: The microflora of the postoperative stomach. $\mathrm{Br} \mathrm{J}$ Surg $68: 560-564,1981$

16）高橋知之, 高木国夫, 野口芳一深：残胃早期癌の 検討. 癌の臨 $29: 25-32,1983$

17) Littler ER, Gleibermann E: Gastritis cystica polyposa. Cancer 29:205-209, 1972

18) Moszkowicz L: Regeneration und Krebsbildungs an der Magenschleimhaut. Arch Klin Chir Langengcks 132: 558-620, 1924

19) Assad RT, Eastwood GL: Epithelial proliferation in human fundic mucosa after antrectomy and vagotomy. Gastroenterology $79: 807-811$, 1980

20) Pulimood BM, Knudsen A, Coghill NF: Gastric mucosa after partial gastrectomy. Gut 17 : 463-470, 1976

21）鵜川四郎：胃切除残胃の青炎について，消内視鏡 の進歩 $18: 47-51,1981$

22) Gjeruldsen ST, Myren J, Fretheim B : Alterations of gastric mucosa following a graded partial gastrectomy for duodenal ulcer. Scand J Gastroenterol 3:465-470, 1968

23) Palmer ED: Further observations on postoperative gastritis. Gastroenterology 25 : 405-415, 1953 